\title{
Pelatihan Bahasa Inggris Secara Intensif Di Desa Jeruk Manis Lombok Utara
}

\author{
${ }^{1}$ Sugianto, ${ }^{2}$ Kamarudin ${ }^{3}$ Ahmad Hanan ${ }^{4}$ Tawali \\ Fakultas Budaya Manajemen dan Bisnis \\ Universitas Pendidikan Mandalika \\ UNDIKMA Mataram \\ Co. Author Email: sugianto@ikipmataram.ac.id
}

\begin{abstract}
Abstrak. Pelaksanaan program pengabdian kepada masyarakat ini bertujuan untuk memberikan intensive care bahasa Inggris ke pada pemuda dan anak-anak usia menengah atas. Mitra yang kami rangkul dalam kegiatan pengajaran bahasa Inggris ini adalah masyarakat desa menggala jeruk manis. Mitra kami berjarak sekitar seratus enam puluh kilo meter dari pusat kota Mataram. Target dari pelaksanaan pengajaran bahasa Inggris ini adalah untuk membantu masyarakat agar dapat menggunakan bahasa Inggris untuk keperluan di sekolah. Sedangkan luaran yang dihasilkan melalui kegiatan pengabdian masyarakat ini adalah laporan akhir kegiatan yang mendokumentasikan seluruh tahapan pelaksanaan kegiatan mulai dari awal sampai akhir kegiatan. Mekanisme pelaksanaan kegiatan pengajaran bahasa Inggris transaksional ini dilakukan dengan tiga tahapan penting yang terdiri dari tahapan perencanaan dan koordinasi, tindakan, dan evaluasi. Setiap tahapan pengabdian ini dilakukan secara kolaborasi dengan tim pengabdian ke pada masyarakat.
\end{abstract}

Kata Kunci: Pelatihan Bahasa Inggris, Intensive care English

\section{PENDAHULUAN}

Desa jeruk manis adalah desa yang terletak di kaki gunung Pusuk sebelah barat. Lokasi ini adalah jalur alternative wisata menuju bangsal dan senggigi melalui lintas pusuk. Pusuk sendiri adalah sebuah destinasi wisata alam yang terkenal dengan keasriannya dan juga hutan monyet atau monkey forest.

Destinasi wisata pusuk menjadi magnet bagi wisatawan baik lokal maupun internasional untuk sekedar mampir memberikan makan kepada monyet-monyet tersebut atau ada yang mengabadikan gambar di daerah wisata alam tersebut. Hal ini tentunya merupakn potensi wisata yang sangat prestisius untuk masyarakat lombok utara yang tinggal di sekitar pusuk karena mereka dilalui oleh jalur emas tersebut. Para wisatawan yang lalu-lalang menuju dank ke bangsal, senggigi, gili dandaerah wisatawan harus singgah disana yang artinya mereka memiliki potensi untuk menghabiskan uang untuk sekedar belanja maupun menginap di daerah tersebut.

Melihat potensi yang dimiliki oleh dusun jeruk manis ini, maka tidak salah jika kita sebagai kaum akademisi memberikan perhatian kepada mereka untuk mentrasfer ilmu bahasa inggris sebagai alat komunikasi ke pada mereka.

Seperti yang kita ketahui bersama bahwa bahasa inggris merupakan bahasa yang digunakan oleh hampir 90 persen wisatawan asing yang berkunjung ke Indonesia. Ini artinaya bahwa bahasa inggris adalah kunci utama bagi masyarakat untuk mengembangkan usaha-usaha pariwisata di desa mereka. Pegawai restoran, toko souvenir, guide, bahkan penyewaan sepeda tetap membutuhkan bahasa inggris sebagai alat komunikasi. Memang bahasa inggris yang ditransfer tidak setinggi yang diajarkan di bangku sekolah namun paling tidak mereka memiliki dasar bahasa inggris untuk dikuasai, sebagai pelecut semangat mereka untuk belajar lebih giat lagi dalam menekuni bahasa inggris. Dari program pengabdian kepada masyarakat inilah diharapkan mereka mampu distimulasi untuk dapat menguasai bahasa Inggris.

Adapun jenis bahasa inggris yang akan ditrasfer kepada masyarakat adalah bahasa inggris daily English yang mengajarkan bagaimana berkomunikasi sehari-hari dan grammar namun tidak selengkap pelajaran grammar yang diajarkan di bangku sekolah. 
Grammar yang dimaksud adalah tenses berupa simple present tense, simple present continuous tense, past tense dan tenses lain yang sering digunakan sehari-hari.

Dengan diajarkannya bahasa inggris ini maka masyarakat diharapkan mampu membangun usaha pariwisata maupun usaha lain yang berdikari apa lagi sampai mampu menyerap tenaga kerja dari penduduk lokal yang ada di sekitar tempat tersebut. Ini tentunya merupakan keuntungan bagi semua kalangan baik pemerintah daerah karena berhasil memberdayakan masyarakatnya yang artinya pertumbuhan ekonomi bagi pemerintah daerah, dan juga keuntungan bagi pihak tim pelaksana dan kampus karena berhasil menanamkan nilai positif dan citra kampus ditengah masyarakat tersebut.

Pada akhirnya program pengabdian kepada masyarakat ini diharapkan agar mampu dilaksanakan secara maksimal dengan melibatkan pula mahasiswa dari Universitas Pendidikan Mandalika Mataram.

Target dari pelaksanaan kegiatan pengabdian pada masyarakat ini adalah bahwa anggota masyarakat yang terlibat dalam program ini mampu menguasai bahasa inggris daily English dan beberapa jenis tensis biasa yang diajarkan oleh tim untuk dimanfaat dalam kehidupannya. Program ini juga diharapkan mampu memotivasi dan menumbuhkan minat masyarakat menguasai bahasa Inggris ketingkat yang lebih tinggi agar mereka dapat meraih pekerjaanpekerjaan lain dengan tingkat penguasaan bahasa inggris yang lebih tinggi seperti tour guide, tour planner dan staff ticketing untuk asing.

\section{PELAKSANAAN PENGABDIAN}

Pelaksanaan kegiatan pengabdian ini rencananya akan mengadopsi mekanisme pelaksanaan program yang diajukan oleh Asep Sopian yakni terdiri dari tiga tahapan inti: perencanaan dan koordinasi, tindakan, dan evaluasi (Asep Sopian: 2012). Pelaksanaan dari masing-masing tahapan dalam kegiatan ini dapat dijabarkan sebagai berikut.

1. Perencanaan dan Koordinasi
Adapun jenis kegiatan-kegiatan yang akan dilakukan pada tahap perencanaan dan koordinasi ini adalah (a) Penyusunan rencana dan mekanisme pelaksanaan pelatihan yang dilakukan oleh tim atau anggota tim Pengabdian kepada masyarakat ini. (b) Melaksanakan pertemuan dengan tokoh-tokoh masyarakat, seperti kades dan tetua desa sebagai bentuk hormat atau ucapan "permisi" karena akan melakukan program bagi masyarakat.

Memberikan pemberitahuan awal tentang kegiatan pelatihan kepada masyarakat

2. Tindakan

Adapun yang dimaksud dengan tindakan dalam kegiatan ini adalah eksekusi atau pelaksanaan program pelatihan yang telah dirancang secara matang. Kegiatan-kegiatan yang dilakukan pada tahap ini adalah (a) Pembentukan kelompok latihan

Memberikan pengetahuan tentang bahasa inggris yang bisa masyarakat gunakan dalam berinteraksi dengan wisatawan. (c) Memberikan contoh cara menggunakan bahasa Inggris seperti; menyapa wisatawan, menawarkan barang jualan kepada wisatawan, bagaimana menjadi seorang tour guide, mengajarkan grammar dan tenses dan lain-lain.

Mempraktikkan secara langsung apa yang telah dipelajari dalam materi latihan.

3. Evaluasi

Evaluasi dilaksanakan untuk menyempurnakan materi dan program pelatihan yang diberikan. Evaluasi sangat penting dilakukan untuk mengetahui kekurangan-kekurangan dan atau kelebihan-kelebihan dari seluruh kegiatankegiatan yang telah dilaksanakan yang kemudian bisa dijadikan sebagai bahan rekomendasi bagi kegiatan-kegiatan pelatihan yang akan dilaksanakan berikutnya.

\section{HASIL DAN PEMBAHASAN}

Hasil yang dicapai dalam pelaksanaan pengabdian kepada masyarakat ini dapat dijabarkan melalui uraian kegiatan yang dilakukan oleh tim pelaksana pada setiap 
proses pelaksanaan yang telah dilalui diantaranya:

\section{A. Koodinasi tim}

Pada tahapan koordinasi, tim melakukan penyusan dan perancangan program pelatihan yang disusun secara bersama-sama oleh seluruh anggota tim pelaksana. Penyusunan rancangan progam ini dimaksudkan untuk mematangkan langkahlangkah yang akan ditempuh dalam pelasanaan program serta memberikan gambaran serta masukan presentase kesiapan design program. Hal-hal yang dipersiapkan oleh tim antaralain adalah design RPP untuk pelatihan, penyusunan materi ajar, slide, media ajar, untuk melatih masyarakat berbahasa Inggris.

Langkah berikutnya pada tahapan petama ini adalah persiapan tutor serta peralatan yang dibutuhkan untuk melakukan kegiatan. Persiapan tutor dan peralatan ini meliputi kegiatan antara lain; mencetak materi pelatihan dan buku panduan untuk yang akan digunakan untuk pelatihan, menyiapkan alatalat kebutuhan seperti LCD projector, laptop atau komputer sebagai alat pendukung utama, alat tulis untuk peserta pelatihan, sound system yang akan digunakan di lapangan, serta modem sebagai media untuk memperoleh akses internet di lapangan karena daerah yang akan dikunjungi memang masih jarang internet akses. Persiapan yang berkaitan dengan tutor sebagai narasumber untuk pelatihan bahasa Inggris dapat dilakukan sendiri oleh ketua dan anggota tim pelaksana karena background knowledge mereka yang merupakan dosen pendidikan bahasa Inggris.

Tahapn selanjutnya adalah meakuka sosialisasi dan koordinasi dengan peserta pelatihan yakni anggota masyarakat. Sosialisasi ini dilakukan untuk memberikan informasi awal tentang kegiatan pelatihan, baik informasi mengenai tujuan program, bagaimana program akan dilakukan, siapa saja yang akan dilibatkan serta manfaat yang dapat diperoleh setiap anggota masyarakat yang mengikuti kegiatan pelatihan.

\section{B. Kegiatan Inti}

Kegiatan inti berupa pelatihan bahasa inggris ini melibatkan anggota masyarakat desa sebagai mitra.. Kegiatan ini disambut antusias oleh seluruh peserta karena memang sudah lama ditunggu demi membuka wawasan masyarakat .

Hasil yang dicapai dari kegiatan penyuluhan pariwisata ini adalah bahwa melalui program pelatihan bahasa inggris ini adalah bahwa mereka dapat memahami dan mampu berkomunikasi dalam bahasa inggris dalam tingkat yang sederhana. Melalui pelatihan ini mereka disadarkan bahwa mereka harus berkompetisi dengan menggunakan skill, bersaing dengan menggunakan keterampilan dan kecakapan atau bahkan jiwa seni yang mereka miliki.

Materi pelatihan bahasa inggris juga membahas tentang bagaimana masyarakat mitra melihat pariwisata sebagai peluang bisnis dan usaha baru yang akan bermanfaat bagi kelangsungan hidup mereka.

Proses pelatihan bahasa inggris yang diberikan meliputi aktivitas aktivitas yang mungkin dihadapi oleh anggota masyarakat saat berkomunikasi dengan wisatawan asing, diantaranya adalah memberikan arahan kepada wisatawan atau dikenal dengan Telling direction dalam Bahasa Inggris, contoh materi conversation:

Local : Excuse me sir, what can I help you?

Excuse me sir, what can I do for you?

Excuse me sir, do you need a help?

Excuse me sir, do you need a hand?

Excuse me sir, do you need a favour?

(pilih salah satu yang paling mudah dan gampang dimengerti)

Tourist Yes please, I would like to go to Pantai Pink

Yes please, I would like to go to pantai Kuta

Can you please show me the way to Awang beach!

I want to go to Pene please,

(tergantung apa yang ditanyakan 
oleh wisatawan)

local : Just go sturight on sir, and then you will find three junction/intersection. And then at the three junction you can turn left/turn right. There will be an intersection, Pantai Pink is about twenty kilometers from it. (tergantung kemana mereka ingin pergi)

Berikutnya adalah materi tentang memberi bantuan kepada wisatawan, Materi ini diberikan kepada para peserta pelatihan bahasa Inggris agar mereka bisa membantu para wisatawan yang dalam terkena musibah misalnya kehabisan bensin, tersesat dan bahkan kehilangan barang.

Contoh pengkondisian yang diberikan adalah:

Teller : Excuse me sir, what happened to your motor cycle sir, may I help you? (menawarkan bantuan)

Tourist : Yes please, the petrol is running out, where do I can find the petrol now? (menanyakan tempat jualan bensin)

Teller: Well sir just go a head, there will be a gass station. Or may be I can go and find it with you sir. (memberikan saran)

Tourist: Oh yes please, thank you anyway

Teller : Here is the gass station sir, how many liter of pertrol do you need?

Tourist: Fill it full please, the distance is still far way alright?

Teller: Seems to be very far sir, any thing I can help you anymore?

Tourist: You are very kind to me. May be next time I will need you.

Ok, this the money, how much I should pay?

Teller : Only twenty thousand rupiah sir

Tourist: Ok here you are.

Teller : Here is your return sir.

Tourist: Tahnk you

Teller : You are welcome.
C. Evaluasi Kegiatan

Evaluasi dilaksanakan untuk menyempurnakan materi dan program pelatihan, evaluasi sangat penting untuk dilakukan untuk mengetahui kekurangankekurangan dan atau kelebihan-kelebihan dari seluruh kegiatan-kegiatan yang telah dilaksanakan yang kemudian bisa dijadikan sebagai bahan rekomendasi bagi kegiatankegiatan yang akan dilaksanakan berikutnya.

\section{KESIMPULAN}

Kegiatan pengabdian kepada masyarakat ini diselenggarakan dengan sukses melibatkan anggota masayrakat di desa jeruk manis lombok utara sebagai partisipan. Masyarakat ikut berpartisipasi dengan sangat antusias dan penuh keseriusan. Ini mereka tunjukkan dengan terus dan rutin mengikuti kegiatan atau program yang kami adakan di desa mereka.

Kemampuan Bahasa inggris yang mereka peroleh mealui pelatihan ini dapat diterapkan di kehidupan sehari hari untuk membantu berkomunikasi dengan wisatawan. Bahasa inggris kontekstual sangat cocok untuk mengajarkan masyarakat agar mereka bisa berbahasa Inggris dalam waktu yang relative singkat karena menitik beratkan pada aspek bahasa sebagai alat komunikasi.

\section{DAFTAR PUSTAKA}

Asep Sopian. (2012) Training Penyuluhan Keagamaan di Kabupaten Subang. Kampus Purwakarta.

Ni Nyoman Parwati,. I Putu Wisna Ariawan. (2013) Laporan Pengabdian Kepada Masyarakat; Media Pembelajaran Matematika SD di Kecamatan Penebel. Universitas Pendidikan Ganesha.

Penny Rahmawaty, et al. (2012) Pemberdayaan Usaha Ekonomi Produktif bagi Masyarakat Miskin di Kota Yogyakarta. Universitas Negeri Yogyakarta.

Tim. (2013) Panduan Pelaksanaan Penelitian dan Pengabdian Kepada Masyarakat di Perguruan Tinggi Edisi IX . Direktorat Jenderal Pendidikan Tinggi 
Abdi Masyarakat

http://ejournal.mandalanursa.org/index.php/PB/issue/archive
Vol. 2. No. 2 Desember 2020

p-ISSN: 2715-8799 e-ISSN: 2715-9108

Kementerian Pendidikan dan

Kebudayaan. 